\title{
COOPERATIVES AND FARMERS ASSOCIATION AS A MODEL OF ENTREPRENEURSHIP IN SERBIAN AGRICULTURE REGARDING THE CASE OF NISAVA DISTRICT ${ }^{1}$
}

\author{
Zoran Simonović, ${ }^{2}$ Branko Mihailović ${ }^{3}$, Zoran Milovanovićc
}

\begin{abstract}
The authors gave a brief overview on the situation of cooperatives in Serbia. They introduce us to the cooperative legislation which wiil be, in the current period, important factor in the development of agricultural cooperatives. Serbia is obligated to harmonize its laws with the laws of European Union. The process of harmonization should be done with the cooperative legislation, too. In the current conditions, the survival of the cooperative is threatened by transition. In the transition process it is required from agricultural cooperatives to return forcefully confiscated land to their rightful owners or their heirs. It is also necessary to return the land taken away from its members and given to the cooperatives to menage it. This process has largely been completed. Some agricultural cooperatives ceased to exist in the transition. At the end, the authors have made a study on the situation in cooperatives in Nišava district. The aim of the research is to analyze the results of the application of the concept of cooperative organization and association of farmers in the transition process.
\end{abstract}

Key words: cooperatives, farmers' associations, cooperatives legislation.

JEL: $Q 1, Q 13, Q 18$.

1 Paper is a part of the research at the project no. III 46006 - Sustainable agriculture and rural development in the function of accomplishment of strategic goals of the Republic of Serbia within the Danube region financed by the Ministry of Education, Science and Technological Development of the Republic of Serbia.

2 Zoran Simonović, Ph.D., Research Associate, Institute of Agricultural Economics, Volgina Street no. 15, 11060 Belgrade, Serbia, Phone: +381 1169728 58, E-mail: zoki@medianis.net

3 Branko Mihailović, Ph.D., Senior Research Associate, Institute of Agricultural Economics, Volgina Street no. 15, 11060 Belgrade, Serbia, Phone: +381 1169728 42, E-mail: brankomih@neobee.net

4 Zoran Milovanović M.A., Regionalna agencija za razvoj istočne Srbije - RARIS, Trg Oslobođenja no. 1, 19000 Zaječar, Phone: +381 648510 263, E-mail: zoran.milovanovic@,raris.org

EP 2016 (63) 2 (699-712) 


\section{Introduction}

Currently, cooperatives in Serbia are the practical organizations. The most of the members, in the modern way of doing business, are inclined to think about meeting their current obligations. This way of thinking influences the cooperative associations to properly examines the way into the future. The cooperative associations are now focused on a pragmatic turn (inclusion), and react to the options in order to adapt to the alterations. The restructuring of our economy is good opportunity for one positively affirmed cooperative association. Certain number of cooperatives are sufficiently large and capable to play important role in this transformation.

Economic reconstruction of agricultural producers can also have inflence on the events related to social changes. Cooperatives can help in reducing of restructuring economy costs. Under such conditions, the cooperatives offer its traditional capacity that can reduce social and economic divisions in the fairer manner.

Modern business conditions of farmers in many ways contribute to their strategic thinking, primarily focused on the function of more efficient cooperative associations. Joining farmers in cooperatives facilitate their joint appearance on the increasingly demanding market. The joining can be viewed through multiple dimensions. Joining resources and financial strengthening are two essential components important for the long-term strategy of the cooperative association. It is suggested certain kind of discipline that will not be easily accomplished. In addition to these two elements of strategic thinking, there are other elements which include the preservation of the security of the cooperative association in general in all situations, in cooperation with government institutions. On the other hand the role of the Government in predicting the future of the cooperative association is in some way in the steady decline. However, the importance of national legislation and policy of determining cooperative organizations implemented by the Government can not be underestimated.

\section{Methodology and data sources}

The authors of this paper used the methods that best reflect the character of the analysis given in the subject. In a study of cooperatives and associations of farmers as a model of entrepreneurship in the agriculture of the Republic of Serbia dominated the quantitative method of economic analysis. These are primarily in the first place the various legal texts, statistical data and literary sources of the cooperative organization. Particularly noteworthy is the empirical research in the area of Nišava District by the method of statistical sample. It should be noted that they used the internet information are numerous and significant.

The contribution of this work is reflected in the review and analysis process of the cooperative organization in the Republic of Serbia. It points to the fact that it is necessary to cooperatives preserve it from further collapse, and that it is necessary to improve its operation and business, and to cooperatives performed its function, it is necessary to stop the decline of agricultural production. It can be more efficient implementation of 
measures of agricultural policy in the creation must be attended by representatives of cooperatives, as the only indigenous organizational segment of farmers in the Republic of Serbia. As the text of this paper believe confirms.

The paper shows that the farmers' association is an advantage, and that means that today it should be like that, especially given the contemporary understanding of agrarian development. The result of this research is as seen in the work of getting to know the full text of the role and importance of full co-operative organization as a potential model for faster start economic activity.

A special contribution is part of the research, which was taken on the basis of empirical research in the area of Nišava District.

The authors have tried to give an insight into the current situation in the Serbian cooperatives. This is deemed necessary today, when the Serbian agriculture is in the final phase of transition and when preparing for accession to the European Union.

\section{Conditions of the cooperative legislation in Serbia since 1989 until today}

After 1989 Serbia has entered in new stage of the cooperatives development. This period is characterized by profound changes in our economic, social and political system. These changes created more favorable conditions for the development of cooperatives. The place and role of cooperatives in the development of economy and society have been determined in a new way. In agriculture, the cooperative is determined as the only and the most important form of economic farmers organization. The main task of cooperatives is to contribute to the strengthening of agriculture, rural households as producers of goods with their activities, to enable them easier engaging in market commodity/money relations and to survive on the markets. (Simonovic et al., 2009).

In Serbia, in 1989, was adopted the Law on Cooperatives and the Law on agricultural cooperatives. At the level of the Yugoslav federation in 1990 was brought federal law on cooperatives. The newly formed Yugoslavia in 1996 brought its own Law on Cooperatives.

According to the law from 1989 cooperatives were formed by farmers, members of their households, working people and citizens and cooperative members, in order to achieve their aims. According to the Federal Law on Cooperatives from 1990 cooperatives are voluntary organizations whose members perform joint operations, achieve economic self-interests and decide on common issues.

According to the Law on Cooperatives of 1996 cooperatives can be established by individuals, on its own initiative, driven primarily by economic as well as other interests. Funds of the work of cooperatives provide members of the cooperative and its members. They guarantee business cooperatives its property and its assets. Through management bodies, cooperative members themselves manage the cooperative affairs. According to this law cooperative ownership is clearly defined. The mechanisms for the protection and reproduction are defined. For the first time the cooperatives audit was 
introduced in the practice, with the aim to create conditions for the uniform application of the cooperative working principles and to eliminate the negative phenomena that accompany the work of cooperative members. (Simonović, et al., 2008).

In light of the current changes in our society, the Ministry of Economy in cooperation with the representatives of other relevant ministries in whose scope of work act different types of cooperatives (agricultural, fishing, consumer, housing, handicraft, savingscredit, service etc.) prepared new version of the Draft law on cooperatives, which was the subject of debate in middle of July 2006, in the Assembly of Vojvodina. On this occasion, representatives of cooperatives and cooperative unions presented number of objections to the draft law. The proposal that immovable property in social ownership, which cooperative or cooperative unions have the right to use, will become state owned asset was especially negatively assessed. Cooperative workers qualified this as new attempt of cooperative ownership nationalization.

After these complaints Ministry of Economy has prepared new, improved version of the Draft Law on Cooperatives. This proposal allows cooperatives and cooperative unions to, within three years from the entry of this law, if they have evidence that the real estate was acquired by work and business or in some other way (a gift, legacy, donation, the final judgment of the State Authority and etc.) translate it from social ownership and enroll it in the land and other public books as cooperative property. This latest version of the law represents improved version of the previous proposal of the Draft Law on Cooperatives.

The Assembly of Serbia on 29 December 2015 adopted new Law on Cooperatives. According to the Law on Cooperatives cooperative represents the voluntary form of organization in which every member participates directly and with joint operations based on cooperative principles aplication, promote and protect their economic, social, professional, cultural and other interests, in accordance with the law and rules of the cooperatives.

The new law still does not address issues such as the rights of employees and workers in relation to members and the role of cooperative associations. On the other hand, more attention is devoted to financial basis of the cooperatives and cooperatives accounts checkings.

We can freely say that the new law allows easier establishments, management, closure and transparency in the operations of cooperatives in compliance with all of the cooperative principles and rules. The improvements that were made in the legal regulation of cooperative organizations are good and desirable. The cooperatives should be organized as family farms organizations. This means that the founders of the cooperative are members of one or two - three households. Otherwise, it can happen that one establishes cooperative with members of his immediate and extended family for speculative purposes. In this way the cooperative would be operated out of the cooperative rules and principles. (Simonovic, Cvijanovic. 2008). According to the new law now cooperatives can be established by at least five founders with the provisio that 
can not live in the same household with the founder.

It is our opinion that the legislator should encourage the establishments of cooperatives by providing greater facilities for an initial period of cooperatives work.

Appropriate training for cooperative managers would create a possibility that the company survives the initial trials and to be included in the job, as soon as possible. (Pejčić 2004).

Cooperative legislation in the current period will be an important factor for the development of agricultural cooperatives. It is our obligation to harmonize our laws with those of the international community. In the European Union, the rule is that all problems have to be solved by legislation. In the European Directorate of the International Cooperative Alliance, was formed a special group of lawyers that will assist in creating legal projects in the field of cooperatives.

\section{Cooperatives in the last phase transition}

The question about the expected response of cooperatives to social and economic changes represents a kind of confrontation with the future of the cooperatives. The cooperative association, in this way, searches for the way to even more people learn about the benefits that can be achieved through a co-operative organizations. This allows for a greater number of people find ways to help themselves and not to be helped in the form of donor dependency. In this way, many worldwide accepted trends are concentrated. These trends are particularly relevant to countries in transition. We will name some of these trends:

- Population growth,

- Increasing concentration of economic power,

- Sustainable development of mankind,

- Increasing difficulties in the normal functioning of the human community,

- Youth employment,

- The issue of social justice. (Zakić, 2001).

Joining farmers because of the structure of farms is the imperative. Cooperatives are most often misused by "civil cooperatives" that do not give producers the ability to completly manage and control the work of the cooperatives. This type of cooperative also has large passive capital. On the other hand "private cooperatives" use the term of the cooperative, but in fact, represent private company, in which producers have no influence. In both cases the idea of cooperatives is destroyed. However, recently, the modern type of cooperatives have been established, in which manufacturers fully participate in decision-making and where they are willing to accept the risk of conquering new markets. However, this type of cooperative has not yet developed enough to have a significant role in the development of the market. 
State cooperatives have processing and storage capacities in its property. State cooperatives manage these capacity on the same or similar manner as they would have done with agrarian combines. The survival of cooperatives in agriculture was threatened by the transition. The transition process requires that agricultural cooperatives return the forcibly seized land to their rightful owners or their heirs. It is also necessary to return the land taken away from cooperative members to cooperatives. This process has largely been completed. Some agricultural cooperatives have disintegrated in transitional movements. However, the most of the agricultural cooperatives continued to exist on the farm land belonging to its members, as well as on land that they purchased over the years. Lately, there has been a loss of motivation for further restructuring of cooperatives. There are needs, on the other side, for modernization of cooperatives operating modes, as well as for Cooperative Union to introduce more modern legislation.

Agricultural cooperatives if they are not as big as agro-conglomerates have the same problems related to the management. These problems are management, lack of investments and redundant, and are faced with the same problems, on the road leading toward profitability.

Agricultural cooperatives are one of the means of agricultural development in the developed economies, especially in the field of marketing, processing and input suppling. Serbia has long tradition of using agricultural cooperatives. However, agricultural cooperatives that were once operated successfully are now close to the state of insolvency or remained completely out of business. Old state agricultural cooperatives provided services to agricultural community during the socialist period by supplying them with agricultural inputs, purchasing and processing the primary products from the private agricultural sector. These cooperatives were unable to achieve the transition to the new market conditions. National cooperatives were cooperatives in name only, while in its essence and by the working methods were, in fact, agricultural enterprises.

The main problem in Serbian cooperatives today is that the largest number of cooperatives fail to comply with the rules, i.e. cooperatives are not managed by cooperative members but either employes in cooperatives in which the workers - cooperative members, in terms of menagment, overcame the producers and continued to self-manage. In private cooperatives cooperative the rules also are not respected because they are registered as cooperatives, but actually in the real sense of the word are private companies owned by one or several individuals. These cooperatives hut overall development of the cooperative sector in Serbia because the most of them do not intend to turn into true cooperatives. Their main goal is to maintain the current status. Cooperative alliances neither want nor are able to deal with this problem that has emerged within the alliance, mainly because they were in alliance structures represented mainly by directors of cooperatives that do not adhere to cooperative rules. The cooperative unions on the other hand have a few manufacturers. Management of Cooperative corresponds to this position and does not want changes. In the cooperative unions there is no clear picture about the situation in the institutional structure. Also, there is no vertical and horizontal integration of cooperatives. 
After the closure of a large number of cooperatives, farmers in the vast number of villages are not mutually commercially organized. In order to alliances to be able to do more for cooperatives in the cooperative organization, it is necessary to be more technically and personnelly organized. When all of these questions are regulated then one can to seek for cooperative alliances responsibility for the development of cooperatives. (Pejčić, 2004). The transformation of the existing cooperative sector should be carried out in accordance with the principles of the ICA and the EU.

On their land, cooperatives should organize a modern production. In current practice, the situation is quite reverse. Cooperatives have lost important land areas by applying various laws on restitution of land that has been transformed into social property. Due to objective inability to return land to farmers because the land changed its purpose, or was sold, the cooperatives plunged into very bad financial situation.

The situation relating to cooperatives in the whole observed period, which covers the period from 1991 to 2011, did not changed considerably. There is continuing trend of cooperative decreasing the from year to year. We noted that the number of cooperatives which did not have land in its own property is the most reduced. Leaseing and renting of the land by these cooperatives have led them to unfavorable poston in relation to the cooperatives with their own land property. (Table 1).

Table 1. Agricultural Cooperative according to the size of land

\begin{tabular}{|c|c|c|c|c|c|c|c|c|c|c|}
\hline Year & In total & Iandless & $\begin{array}{c}\text { to 50 } \\
\text { hectares }\end{array}$ & $\mathbf{5 1 - 1 0 0}$ & $\begin{array}{c}\mathbf{1 0 1 -} \\
\mathbf{3 0 0}\end{array}$ & $\begin{array}{c}\mathbf{3 0 1 -} \\
\mathbf{5 0 0}\end{array}$ & $\begin{array}{c}\mathbf{5 0 1 -} \\
\mathbf{1 0 0 0}\end{array}$ & $\begin{array}{c}\mathbf{1 0 0 1 -} \\
\mathbf{2 5 0 0}\end{array}$ & $\begin{array}{c}\mathbf{2 5 0 0 -} \\
\mathbf{5 0 0 0}\end{array}$ & $\begin{array}{c}\text { Over } \\
\mathbf{5 0 0 0}\end{array}$ \\
\hline 1991 & 783 & 454 & 60 & 64 & 91 & 30 & 41 & 32 & 8 & 3 \\
\hline 1995 & 750 & 416 & 91 & 55 & 78 & 31 & 38 & 32 & 7 & 2 \\
\hline 2000 & 575 & 278 & 83 & 32 & 72 & 32 & 43 & 26 & 7 & 2 \\
\hline 2001 & 536 & 241 & 78 & 37 & 69 & 34 & 40 & 29 & 7 & 1 \\
\hline 2002 & 510 & 208 & 84 & 38 & 70 & 35 & 39 & 28 & 7 & 1 \\
\hline 2003 & 467 & 187 & 69 & 36 & 65 & 38 & 35 & 29 & 7 & 1 \\
\hline 2004 & 460 & 173 & 77 & 29 & 70 & 38 & 37 & 28 & 7 & 1 \\
\hline 2008 & 260 & 23 & 64 & 40 & 60 & 27 & 24 & 15 & 6 & 1 \\
\hline 2009 & 264 & 2 & 56 & 37 & 57 & 38 & 43 & 25 & 5 & 1 \\
\hline 2010 & 257 & 43 & 62 & 31 & 59 & 22 & 23 & 12 & 4 & 1 \\
\hline 2011 & 218 & 32 & 52 & 22 & 59 & 17 & 21 & 11 & 3 & 1 \\
\hline
\end{tabular}

Source: Statistical Yearbook RS, 2011

Agricultural cooperatives in Serbia are located in a specific position which is caused by the transition process. The general assessment is that the cooperatives and agriculture fell into great difficulties. In Serbia, there are currently only 218 agricultural cooperatives with thousands of members and few hundred thousand subcontractors. The falling trend of cooperatives is still present. Besides the Cooperative Association of Serbia there are two provincial and twelve district associations. Some of these cooperatives are traditionally known as companies with long tradition of cooperatives. Due to the poor economic situation that is present, many cooperatives have stopped 
working. The inadequate agricultural policy has also contributed to many cooperatives have lost their jobs. Cooperatives, which based its activity on the resources of farmers - cooperative members, have managed to avoid difficulties. They represent strong and stable organizations. (Govedarević, 2004).

The safe way to improve the cooperative organization is to improve the quality of agricultural products, which is reflected in the use of modern technological know-how, in the production and marketing innovation strategies, in order to offer quality in a quality manner accessible to customers both at home and abroad. We do not have good marketing for domestic goods. We do not know how to brand what we produce and to firmly bound it to the consumers. (Hamović, et al., 2006).

The expected improvement in the business environment should be derived from the new Law on Cooperatives. The new law should be of basis for a simple and clear manner of the field regulation and to contribute to increasing the motivation and interest in the establishment of cooperatives. In addition, improvment of the cooperative sector will be achieved through the inclusion of advisers for agricultural associations in order to assist in the creation, establishment and effective functioning of cooperatives in Serbia. (Chroneos-Krasavac, Petković, 2015).

The National Assembly of Serbia adopted the new law on cooperatives on the 29.12.2016. The biggest changes compared to the previous law are related to the role of cooperatives, cooperative audit and registration of cooperative property.

\section{Cooperatives in Nišava district}

In order to show the state of cooperatives in Nišava district we have done the research. The aim of the research is to analyze the results of the application of the concept of cooperative organization and association of farmers in the transition process. We prepared a special questionnaire, for this survey.

Nišava district has, according to the state from 2012, 31,709 farms. If one takes sample of $0.5 \%$ then there are 159 households to be interviewed (see Table 2).

Table 2. Number of households Nišava district according to the state 2012th

\begin{tabular}{|c|r|r|}
\hline Municipality & Agricultural holdings & $\begin{array}{c}\text { The required number of } \\
\text { polling 0,5\% }\end{array}$ \\
\hline Aleksinac & 7116 & 36 \\
\hline Gadžin Han & 2159 & 11 \\
\hline Doljevac & 3733 & 19 \\
\hline Merošina & 3074 & 15 \\
\hline Niš & 10244 & 51 \\
\hline Ražanj & 2332 & 12 \\
\hline Svrljig & 3051 & 15 \\
\hline In total & 31709 & 159 \\
\hline
\end{tabular}

Source: Statistical Yearbook RS and Calculation of the authors based on survey. 
Good number of survey sheets were filled by the author himself on the field. When filling out surveyes he interview for the surveyed persons and became acquainted with the state instruments of labor, buildings, orchards, etc. That is to say that besides the method of surveying, the interview method is, to some extent, presented (interview as a method of direct observation and insight in the household).

On the first question: Are you a member of an association or subcontractor of a farmers and agricultural cooperatives? We got the following answers:

Table 3. Belonging to a cooperative or an association of farmers

\begin{tabular}{|c|c|}
\hline Answers of respondents & Share in \% \\
\hline Yes & 40,88 \\
\hline No & 57,23 \\
\hline without answer & 1,89 \\
\hline In total $\mathrm{H}=159$ & 100,0 \\
\hline
\end{tabular}

Source: Calculation of the authors based on survey.

Almost half of the surveyed household's owners are members of one of the associations in their area.

We asked surveyed farmers that are members of associations or cooperatives to which assosiation or cooperative they belong. We got the list of a large number of associations. One gets the impression that all these associations and cooperatives have small number of members. This is probably their main problem when entering the market.

Cattlemen's Beef Association Čokot

Agro product Donje Međurovo

Cattlemen's Beef Association Lalinac

Association of Fruit and Wine Gabrovac

Agricultural Cooperative Gabrovac

Agricultural Cooperative Čegar Donji Matejevac

Fruit Association Čegar Gornji Matejevac 2

Goat Breeder Association Milky way Gabrovac

Association of Fruit Matejevac 2

Association of farmers and growers Oreovac

Association of Fruit Growers, vintners and growers Pantalej Donji Matejevac 3

Association of pig breeders ,Three pigs“" Hum

Niški Association farmers and seed Hum 2

Cattlemen's Beef Association “Ada” Sečanica 2

Association "105 +" Sečanica

EP 2016 (63) 2 (699-712) 
The snail cooperatives "Helix" Supovac

Groups of women farmers Gornja Trnava

Association "Future" Leskovik

Association "Euro milk" Hum

Association "Progress" Trupale

Joining farmers through cooperatives and other associations is diverse. Most of joined farms are in Merošina $87 \%$ and $50 \%$ of Niš, the least in Gadžin Han and Doljevac, over $80 \%$ of households are not members of any association.

Nearly $40 \%$ of respondents that are members of the associations gave their written comments in the survey when completing and related to the advantages of the surveys.

Table 4. Written comments on the benefits of farmers association membership of only those farms that belong to them

\begin{tabular}{|l|l|}
\hline Answers of respondents & Share in\% \\
\hline did not write & 61,01 \\
\hline write & 38,99 \\
\hline In total $\mathrm{H}=159$ & 100,0 \\
\hline
\end{tabular}

Source: Calculation of the authors based on survey.

About $23 \%$ of those who are members of the associations gave their written comments in the survey when completing, related to disadvantages of the surveys.

Table 5. Written comments on disadvantages of farm cooperative membership only from those households that belong to them

\begin{tabular}{|l|lr|}
\hline Answers of respondents & Share in\% & \\
\hline did not write & & 76,73 \\
\hline write & 23,27 \\
\hline In total $\mathrm{H}=159$ & 100,0 \\
\hline
\end{tabular}

Source: Calculation of the authors based on survey.

More than $60 \%$ of the surveyed farm holders claimed that there was no cooperatives and associations on theirs territory, although the number of farm holders who claim that they cannot benefit from them is not small.

Table 6. What are the reasons to belong to an association or cooperative farmers?

\begin{tabular}{|l|l|}
\hline Answers of respondents & Share in\% \\
\hline I can realize significant benefits & 28,24 \\
\hline no associations & 50,59 \\
\hline no cooperatives & 16,47 \\
\hline something else & 4,706 \\
\hline In total $\mathrm{H}=159$ & 100,0 \\
\hline
\end{tabular}

Source: Calculation of the authors based on survey. 
On the question how do you sell your products? the largest number of surveyed farm holdars stated that marketing of agricultural products is a major constraint, also it is not small number of those who identified the lack of support from the agricultural budget of the country as the biggest limitation.

Table 7. Methods of sales of agricultural products

\begin{tabular}{|l|r|r|}
\hline Answers of respondents & number of holdings & Share in \% \\
\hline through cooperatives & 17 & 10,7 \\
\hline in person at the market & 97 & 61,0 \\
\hline companies & 17 & 10,7 \\
\hline middlemen & 14 & 8,8 \\
\hline directly to processors & 9 & 5,7 \\
\hline in total & 154 & 96,9 \\
\hline without answer & 5 & 3,1 \\
\hline in total & 159 & 100,0 \\
\hline
\end{tabular}

Source: Calculation of the authors based on survey.

When it comes to sales carried out by farms that used incentives, plased their products mainly (in $50 \%$ of cases) on markets, through cooperatives (18\%), companies and processors $(15 \%)$. The farms that did not use programs for agriculture, made more than $70 \%$ of the sale on the markets and trough dealers $(12 \%)$. The users of incentives and those who are not claimed that in more than $60 \%$ of the cases product placement is the main limiting factor. We note interesting fact reflected in the fact that the beneficiaries of the measures for agriculture are less satisfied with financial support from the agricultural budget than those who did not benefit from incentives.

Table 8. The major limitations of agricultural production

\begin{tabular}{|l|r|r|}
\hline & Number of farms & Share in\% \\
\hline placement & 102 & 64,2 \\
\hline source of funding & 16 & 10,1 \\
\hline not belonging to an association or cooperative & 6 & 3,8 \\
\hline low support from the agricultural budget & 35 & 22,0 \\
\hline in total & 159 & 100,0 \\
\hline
\end{tabular}

Source: Calculation of the authors based on survey.

Also, on the basis of the survey, we noted that more than half of the farms that have used incentives are members of an association of farmers, while those who did not use measures of support in over $70 \%$ of cases, unfortunately, are not. As regarding to territorial representation the largest number of users is in Aleksinac municipality $(30 \%)$, the City of Nis $(20 \%)$ and the smallest number is in municipalities of Gadzin Han and Doljevac, below 5\%. Almost all farms registered in the unified register of agricultural farms used one of the measures for agriculture, it cannot be said for nonregistered farms. The biggest beneficiaries of incentives are agricultural and mixed farms. The users of incentive funds have mainly used the funds of the improvement in animal husbandry, horticulture, farming and vegetable growing. 


\section{Conclusion}

In the future times cooperatives need to be face with two issues. First, how to become more effective and second how to respond to social and economic changes. At the time when Serbia is in the process of transition and accession to the European Union these are questions most frequently asked by members of the cooperatives, elected leaders, managers and employes.

According to many parameters, they are unique organizations. Cooperatives in its basic structure and elements of ideology carry theirs own success. Parameters of cooperative success are: priority of the cooperative membership, cooperative diversity, strengthening the economic power of people, careful management of resources, the creation of the financial power of the people, strategic thinking.

All of this is supposed to represent the future of what could real and achievable in the system of allocating strategic association with farmers.

The reasons for the failure of cooperatives can be found in the disantvages of the previous Law on Cooperatives, which was adopted in 1996 and amended in 1998. Previous fifteen years are characterized by ruining the cooperative assosiations, evolving away from the cooperative principles and market economy. The state, with its repeated interventions, not only in the cooperative, but also in other areas of economic activity has contributed to reducing the farmers confidence in cooperatives, as well as the connection and association of farmers in general.

In order to preserve the cooperatives from further collapse and to improve their work and business, and to perform its functions, it is necessary to stop the decline in agricultural production - as much as possible by implementing more efficient measures of agricultural policy, which creation must be attended by representatives of cooperatives, as the only indigenous organizational segment of farmers in our Republic. Adequate implementation the agricultural policy includes the implementation of the goals of development and security, which practically means that the state provides incentives for the development of agriculture, must reach the right customers - primary agricultural producers - members.

The new law on cooperatives is the attempt to rescue cooperatives and the cooperative assosiations in our country. Time will tell whether this law was adopted with large delay. On the basis of all that we exposed, it can be emphsized that it is necessary to adopt strategy for the development of cooperatives in Serbia.

\section{Literature}

1. Chroneos-Krasavac, B., Petković, G. (2015): Cooperatives in Serbia: Evolution and current issues. Ekonomika poljoprivrede, vol. 62, no. 3, pp.723-735.

2. Zakić Z. (2001): Agrarna ekonomija, CID, Ekonomski fakultet Beograd.

3. Gnjatović, D. (2010): Zemljoradničke kreditne zadruge - prve institucije za finansiranje razvoja poljoprivrede u Srbiji. Bankarstvo, vol. 39, no. 3-4, pp.14-35.

4. Govedarević D. (2004): Stanje i razvojne mogućnosti poljoprivrednog zadrugarstva Srbije, Zadružni savez Srbije, Beograd. 
5. Iliopoulos, C. (2013): Public policy support for agricultural cooperatives: an organizational economics approach. Annals of Public and Cooperative Economics, 84(3), pp. 241-252.

6. Marković, K. (2007): Poljoprivredno zadrugarstvo u Republici Srbiji - stanje $i$ perspektive. Letopis naučnih radova Poljoprivrednog fakulteta, vol. 31, no. 1, pp. 114-121.

7. Nilsson, J. (1998): The emergence of new organizational models for agricultural cooperatives. Swedish Journal of agricultural research, vol. 28, no. 1, pp. 39-47.

8. Nilsson, J., Svendsen, G. L., \& Svendsen, G. T. (2012): Are large and complex agricultural cooperatives losing their social capital? Agribusiness, vol. 28, no. 2, pp. 187-204.

9. Ortmann, G. F., King, R. P. (2007): Agricultural cooperatives I: History, theory and problems. Agrekon, vol. 46, no. 1, pp. 18-46.

10.Österberg, P., \& Nilsson, J. (2009): Members' perception of their participation in the governance of cooperatives: the key to trust and commitment in agricultural cooperatives. Agribusiness, vol. 25, no. 2, pp. 181-197.

11.Pejčić H. (2004): Ekonomika poljoprivrede, Ekonomika, Niš.

12.Pejčić, H. (2004): Današnje poljoprivredno zadrugarstvo. Ekonomika, vol. 50, no. 6, pp. 134-138.

13.Simonovic Z., Mihailovic B., \& Hamovic V., (2009): The Serbian System of Co-operative Society in Conditions of Evolution and Transition, Simpozionul International cu tema, Competitivitatea agriculturii Romanesti in procesul de integrare Europeana, ARS Academica, Bucuresti, pp. 534.

14.Simonović, Z., Cvijanović, D. (2008): Neki aktuelni problemi zadrugarstva Srbije u tranzicionim kretanjima. Ekonomika, vol. 54, no. 1-2, pp. 131-138.

15.Simonović, Z., Arsenijević, Ž., Mihailović, B. (2008): Zadrugarstvo Srbije u uslovima evolucije i tranzicije. Ekonomika poljoprivrede, vol. 55, no. 3, pp. 319328.

16. Simonović, Z. (2005): Zemljoradnička zadruga u uslovima tranzicije. Ekonomika, 51(4), pp. 31-36.

17.Hamović V., Paraušić V., Mihailović B. (2006): Konkurentnost srpske privrede u funkciji podsticanja izvoznih aktivnosti, Ekonomika poljoprivrede, 53 Tematski broj, Beograd, pp. $449-451$.

18.Zakić, N., Vukotić, S., Cvijanović, D. (2014): Organizacioni modeli u poljoprivredi sa posebnim osvrtom na male poljoprivrednike. Ekonomika poljoprivrede, vol. 61, no. 1 , pp. 225-237.

19.Zakon o zemljoradničkim zadrugama, Službeni glasnik SR Srbije, br. 59/1989.

20.Zakon o zadrugama, Službeni list SFR Jugoslavije br 3/1990.

21.Zakon o zadrugama, Službeni list SR Jugoslavije br. 41/1996.

22.Nacrt zakona o zadrugama, Republika Srbija, Ministarstvo privrede, (available EP 2016 (63) 2 (699-712) 
at: $\quad$ http://www.privreda.gov.rs/wp-content/uploads/2015/09/Nacrt-Zakona-OZadrugama2.pdf )

23.Zeuli K., Cropp R., (2004), Cooperatives: Principles and Practices in the 21st Century, University of Wisconsin, Extension - Madison.

\title{
ZADRUGE I UDRUŽENJA POLJOPRIVREDNIKA KAO MODEL PREDUZETNIŠTVA U POLJOPRIVREDI SRBIJE SA OSVRTOM NA STANJE U NIŠAVSKOM OKRUGU ${ }^{5}$
}

\section{Zoran Simonović, ${ }^{6}$ Branko Mihailović ${ }^{7}$ Zoran Milovanovic ${ }^{8}$}

\begin{abstract}
Apstrakt
Autori u radu daju kratak prikaz stanja u zadrugarstvu Srbije. Upoznaju nas sa zadružnim zakonodavstvom koje će u postojećem periodu biti važan faktor u razvoju zemljoradničkog zadrugarstva. Srbija se nalazi u obavezi da harmonizuje svoje zakone sa zakonima Evropske unije. Taj postupak harmonizacije je potrebno uraditi $i$ sa zadružnim zakonodavstvom.

Upostojećim uslovima opstanak zadruga bioje ugrožen tranzicijom. U procesu tranzicije zahteva se od poljoprivrednih zadruga da vrate nasilno oduzetu zemlju njihovim pravim vlasnicima ili njihovim naslednicima. Takođe je neophodno da se vrati i zemljište oduzeto od zadrugara, a dato je na upravljanje zadrugama. Ovaj proces je u velikoj meri već završen. Pojedine poljoprivredne zadruge su prestale da postoje u tranziciji.

Na kraju rada autori su dali istraživanje o stanju zadrugarstva u Nišavskom okrugu. Cilj istraživanja je da se sagledaju rezultati primene koncepta zadružnog organizovanja i udruživanja poljoprivrednika u procesu tranzicije.
\end{abstract}

Ključne reči: zadruge, udruženja poljoprivrednika, zadružno zakonodavstvo

5 Rad je deo istraživanja na projektu broj III 46006: „Održiva poljoprivreda i ruralni razvoj u funkciji ostvarivanja strateških ciljeva Republike Srbije u okviru dunavskog regiona“ koji finansira Ministarstvo prosvete, nauke i tehnološkog razvoja Republike Srbije u periodu 2011-2014.

6 Dr Zoran Simonović, Naučni saradnik, Institut za ekonomiku poljoprivrede, Volgina ulica br. 15, 11060 Belgrade, Srbija, Telefon: 01169728 58, E-mail: zoki@,medianis.net.

7 Dr Branko Mihailović, Viši naučni saradnik, Institut za ekonomiku poljoprivrede, Volgina ulica br. 15, 11060 Beograd, Srbija, Telefon: 01169728 42, E-mail: brankomih@neobee.net.

8 Magistar Zoran Milovanović, Regionalna agencija za razvoj istočne Srbije-RARIS, Trg Oslobođenja br. 1, 19000 Zaječar, Telefon: +381 648510 263, E-mail: zoran.milovanovic@raris.org 